\title{
Impact of TOEFL Score Implementation on Completion Duration of Students Study
}

\author{
Zaitun, Syamsuddin, and Muhammad Sayuthi
}

\begin{abstract}
The students generally difficult to achieve a TOEFL score that is in accordance with the requirements for final exams. Student difficulties in achieving the desired TOEFL score affects the length of a student's study. Based on this, it is necessary to research for the best solution by involving students and leadership of study program through Focus Group Discussion (FGD), surveys, and training. The results of this study concluded that: (1) In general, student TOEFL score is $<477$ and to achieve TOEFL score $\geq 477$ students must do the TOEFL test more than five times; (2) The provision of training to the students TOEFL preparation can increase the TOEFL score and reached $\geq 477$; and (3) it needs the active role of the study program, faculty and students to increase the TOEFL score of students, so that students study period will be shorter.
\end{abstract}

Keywords — English, Study duration, TOEFL

\section{INTRODUCTION}

TOEFL score is one of the requirements that must be met by the student to be able to follow the final exam. TOEFL score is a requirement for students to be able to follow the Magister Program final exam is $\geq 477$ [3]. Some of the problems posed by the implementation of TOEFL scores as a condition of final exams are: (1) inhibition of the students to be able to pass quickly; (2) TOEFL become a burden for students, especially for students with low English skills; (3) add to the cost of study as to obtain TOEFL scores should follow the TOEFL test and the test execution cost that must be paid by the student.

The objectives of the research was : (1) to determine the average TOEFL scores achieved by students; and (2) to determine the appropriate methods to improve student TOEFL scores.

Based on information obtained will be known to the problems faced by students in achieving the TOEFL score. While on the other hand, will do the assessment on the rules that have been imposed by the institution or program of study related to the implementation of TOEFL score. Based on these two studies, both from the students and the policy holder in college or study program will be known gap between the two sides, so this research will be pursued to find a good solution

Zaitun is with Agrotechnology Study Program, Agriculture Faculty, Syiah Kuala University, Banda Aceh, Indonesia

Syamsuddin is with Agrotechnology Study Program, Agriculture Faculty, Syiah Kuala University, Banda Aceh, Indonesia

Muhammad Sayuthi is with Plant Protection Study Program, Agriculture Faculty, Syiah Kuala University, Banda Aceh, Indonesia to solve the problem TOEFL constraints in completing the study for students.

\section{METHODS}

An action research study involving people in a given setting to bring about change on a particular issue. By involving others in doing research, action research can lead to more selftransformation and consensus about the changes made [2]. Action research has a positive effect for many reasons, the most important is that action research is always relevant to the audience. Relevance is guaranteed because the focus of each research project is determined by the researcher, who is also the main consumers of research findings.

The method used in this research is survey method. This method is used to express a truth that is focused on the object of research, ie component (students) were involved in studies on Magister Agroecotechnology Study Program. Sampling these students using simple random sampling method, the sample is drawn at random from all members of the graduate student Agroecotechnology. From the number of graduate student Agroecotechnologi, then 50\% of samples taken from the number of each class of students on the basis that student members are homogeneous.

The analysis technique used in this study using qualitative analysis techniques. Qualitative data analysis is the process of systematically searching for and compiling data obtained from the results of observation interviews, questionnaires and documentation study. Qualitative data analysis techniques are closely related to data collection methods, so that the data collected by interview, questionnaire, observation and documentation study also deals with the qualitative data analysis methods used [1].

The method of analysis used in this research is descriptive analysis method. This method is a method to the way data is analyzed to illustrate and interpret the objects according to what is or explain phenomena that occur around the object of research with a view to find a way of determining the research [5]. Through this method will be identified how the implementation of TOEFL scores to students and the impact of the TOEFL score application on the duration of student study.

Besides the survey method, the research also conducting TOEFL Preparation training to the students of the Magister Agroecotechnology, Graduate Program, Syiah Kuala University. Students tested their English skills are divided into two groups, such as students who were trained and that did not 
get training. This grouping to determine whether the provision of training effective to improve student TOEFL scores. Students from both groups will be tested TOEFL two times, namely at the beginning and end of the training. Based TOEFL test results will be examined whether there is a difference between students who receive TOEFL preparation training with no training.

\section{RESUlt AND DisCUSSION}

\section{A. Focus Group Discussion (FGD)}

FGD held to discuss the implementation of research activities and also to discuss the material and questions on the survey that will be conducted by students of the Magister Agroecotechnology as respondents. Some of the discussions and recommendations have been agreed in FGD are :

a. The number of respondents is 50 (fifty) students from various class in the Magister Agroecotechnology.

b. The number of students who will participate in the initial test TOEFL is 30 (thirty) students.

c. Of the 30 (thirty) students will be divided into 2 (two) groups: 15 (fifteen) students will follow TOEFL preparation training, and 15 (fifteen) students did not include the TOEFL preparation training.

d. The results of the activity section (c) will be compared and note whether the activity TOEFL preparation training will be effective for improving student TOEFL score.

e. The types of questions in the survey activities.

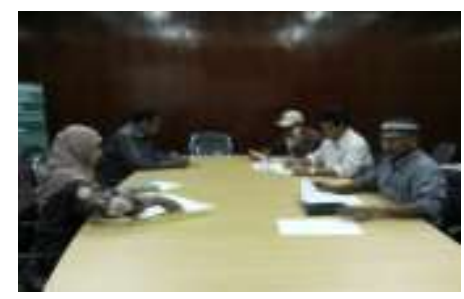

Fig. 1 Focus Group Discussion (FGD) activity

\section{B. Survey Activity}

TOEFL surveys have been implemented by students of the Magister Agroecotechnology as respondents. There are 50 (fifty) students who have participated in this survey. The objective of the survey was to investigate and obtain information on English proficiency and ever/absence of English course or TOEFL before.

Based on the survey results that have been made known that respondents more male than female (Table 1) and the age of the respondents is generally between 20 to 29 years (Table 2). In general, the students participating in the survey had studied English since the age of 10-14 years (Table 3) with long learning English 5-9 years (Table 4). English learned by students not only at school, but they also learn English at a language course. Besides on courses, students also study independently through electronic media and books, and there is also a study with friends or family at home (Table 5).

In English lessons there are some subjects or parts of focus, ie (1) listening, (2) speaking, (3) reading, and (4) writing. Based on the focus that listening is the most preferred and also the most difficult to learn than English according to the respondents (Tables 6 and 7).

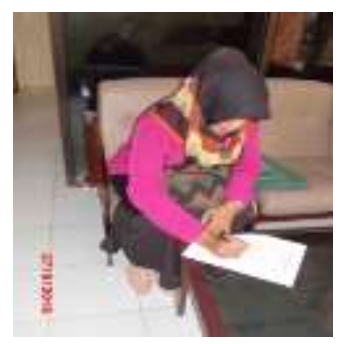

Fig. 2 Survey activity by student

TABLE I

THE SURVEY PARTICIPANTS BY GENDER

\begin{tabular}{clcc}
\hline \hline No & Gender & Total (Persons) & Persentation (\%) \\
\hline 1 & Male & 27 & 54 \\
2 & Female & 23 & 46 \\
\hline & Total & 50 & 100 \\
\hline \hline
\end{tabular}

TABLE II

SURVEY PARTICIPANTS UNDER STUDENTS AGE

\begin{tabular}{|c|c|c|}
\hline Age (Years) & Total (Persons) & Persentation (\%) \\
\hline $20-29$ & 30 & 60 \\
\hline $30-39$ & 14 & 28 \\
\hline $40-49$ & 5 & 10 \\
\hline $50-59$ & 1 & 2 \\
\hline Total & 50 & 100 \\
\hline \multicolumn{3}{|c|}{$\begin{array}{c}\text { TABLE III } \\
\text { AGE START LEARNING ENGLISH } \\
\end{array}$} \\
\hline $\begin{array}{c}\text { Age Start Learning English } \\
\text { (Years) }\end{array}$ & Total (Persons) & Persentation (\%) \\
\hline $5-9$ & 4 & 8 \\
\hline $10-14$ & 43 & 86 \\
\hline $15-19$ & 1 & 2 \\
\hline $20-24$ & 0 & 0 \\
\hline $25-29$ & 1 & 2 \\
\hline $30-34$ & 1 & 2 \\
\hline Total & 50 & 100 \\
\hline \multicolumn{3}{|c|}{$\begin{array}{c}\text { TABLE IV } \\
\text { DURATION LEARNING ENGLISH } \\
\end{array}$} \\
\hline $\begin{array}{c}\text { Duration Learning English } \\
\text { (Years) }\end{array}$ & Total (Persons) & Persentation (\%) \\
\hline $0-4$ & 4 & 8 \\
\hline $5-9$ & 23 & 46 \\
\hline $10-14$ & 12 & 24 \\
\hline $15-19$ & 6 & 12 \\
\hline $20-24$ & 4 & 8 \\
\hline $25-29$ & 1 & 2 \\
\hline Total & 50 & 100 \\
\hline
\end{tabular}


TABLE V

PLACES LEARNING ENGLISH

\begin{tabular}{|c|c|c|}
\hline $\begin{array}{l}\text { Places Learning English } \\
\text { (Beside School) }\end{array}$ & Total (Persons) & Persentation (\%) \\
\hline Course & 32 & 64 \\
\hline Google Translate & 1 & 2 \\
\hline Campus & 1 & 2 \\
\hline Book & 1 & 2 \\
\hline Home & 2 & 4 \\
\hline Electronic Media & 1 & 2 \\
\hline Friends & 1 & 2 \\
\hline Not answer & 11 & 22 \\
\hline Total & 50 & 100 \\
\hline \multicolumn{3}{|c|}{$\begin{array}{c}\text { TABLE VI } \\
\text { THE MOST FAVORED OF ENGLISH }\end{array}$} \\
\hline The Most Favored of English & Total (Persons) & Persentation (\%) \\
\hline Listening & 19 & 38 \\
\hline Speaking & 13 & 26 \\
\hline Reading & 16 & 32 \\
\hline Writing & 2 & 4 \\
\hline Total & 50 & 100 \\
\hline \multicolumn{3}{|c|}{$\begin{array}{c}\text { TABLE VII } \\
\text { THE MOST DIFFICULT FROM ENGLISH }\end{array}$} \\
\hline
\end{tabular}

The Most Difficult from English Total (Persons) Persentation (\%)

\begin{tabular}{ccc}
\hline Listening & 18 & 36 \\
Speaking & 17 & 34 \\
Reading & 0 & 0 \\
Writing & 15 & 30 \\
\hline Total & 50 & 100 \\
\hline \hline
\end{tabular}

The understanding in English will greatly assist students in following the TOEFL test. Although most students have studied English since the age of 10 years, but in fact the students are still experiencing difficulties in learning and understanding English. Lack of understanding of the English language has an impact on TOEFL test scores are low. TOEFL scores lower impact on duration of students study. This is because the TOEFL score is one of the mandatory requirement that must be met by students in order to follow final exam. Based Curriculum Guide Magister Program Agroecotechnology and the Rector of Syiah Kuala University Statement Letter is known that the TOEFL requirement for students to follow final exam is $\geq 477$.

In the TOEFL test, there are 3 (three) topic or focus that became the basis of assessment, ie : (1) Structure and Written Expression, (2) Reading Comprehension, and (3) Listening Comprehension. Based on the survey results note that Reading Comprehension is the easier part of the TOEFL test, whereas Structure and Written Expression is the most difficult (Table 8). Poor understanding of the English language and the difficulty in following the TOEFL test lead to students having difficulty in achieving TOEFL score in accordance with the requirements of final exam $(\geq 477)$. In order to achieve the appropriate requirements, students generally have to do several times (> 5 times) TOEFL test (Table 9). This has an impact on the length of time students in completing their studies.

TABLE VIII

EASY AND DIFFICULT PARTS OF THE TOEFL TEST

\begin{tabular}{lcccc}
\hline \hline & \multicolumn{2}{c}{ Easy } & \multicolumn{2}{c}{ Difficult } \\
\cline { 2 - 5 } Parts of the TOEFL Test & $\begin{array}{c}\text { Total } \\
\text { (Persons) }\end{array}$ & $\begin{array}{c}\text { Persentation } \\
(\%)\end{array}$ & $\begin{array}{c}\text { Total } \\
\text { (Persons) }\end{array}$ & $\begin{array}{c}\text { Persentation } \\
(\%)\end{array}$ \\
\hline $\begin{array}{l}\text { Structure and Written } \\
\begin{array}{l}\text { Expression } \\
\text { Reading Comprehension }\end{array}\end{array}$ & 4 & 8 & 25 & 50 \\
$\begin{array}{l}\text { Listening } \\
\text { Comprehension }\end{array}$ & 11 & 70 & 2 & 4 \\
\multicolumn{1}{c}{ Total } & 50 & 100 & 50 & 100 \\
\hline \hline
\end{tabular}

TABLE IX

FOLLOWING THE TOEFL TEST

\begin{tabular}{ccc}
\hline \hline Following the TOEFL test for & Total (Persons) & Persentation (\%) \\
TOEFL score of $\geq 477$ (times) & 2 & 4 \\
1 & 6 & 12 \\
$<3$ & 16 & 32 \\
$3-5$ & 24 & 48 \\
$>5$ & 2 & 4 \\
\hline Not answer & 50 & 100 \\
\hline Total &
\end{tabular}

TABLE $X$

THE USE OF ENGLISH IN TEACHING ACTIVITIES

\begin{tabular}{lcccc}
\hline \hline \multirow{2}{*}{$\begin{array}{c}\text { The use of English } \\
\text { in Teaching } \\
\text { Activities }\end{array}$} & \multicolumn{2}{c}{ Use } & \multicolumn{2}{c}{ Not use } \\
\cline { 2 - 5 } (Persons) & $\begin{array}{c}\text { Persentation } \\
(\%)\end{array}$ & $\begin{array}{c}\text { Total } \\
\text { (Persons) }\end{array}$ & $\begin{array}{c}\text { Persentation } \\
(\%)\end{array}$ \\
\hline $\begin{array}{l}\text { Paper/college } \\
\text { assignment }\end{array}$ & 44 & 88 & 6 & 12 \\
$\begin{array}{l}\text { Explain lectures in } \\
\text { the classroom }\end{array}$ & 28 & 56 & 22 & 44 \\
$\begin{array}{l}\text { Presentation } \\
\text { material in class }\end{array}$ & 42 & 84 & 8 & 16 \\
\hline \hline
\end{tabular}

The understanding of English by the students would be increased if supported by the conditions in the class with lecturers active participation. Application of English on the activity in the class will help students to further improve to English. Application of English on the activity of the lecture can be: (1) the provision of duty in English, (2) a lecture presentation materials, and (3) the lecturer explain lectures in English. Based on the survey results it is known that the application of English in the class activity is to provide a paper/college assignment (Table 10).

\section{TOEFL Preparation Training}

Students tested their English skills are divided into two groups, such as students who were trained and that did not get training. In each group carried out preliminary TOEFL tests prior to the start of the training program TOEFL Preparation. Based on the initial results of the TOEFL test is known that none of the students who receive a TOEFL score $\geq 477$ (Table 11). It reveals that in general English proficiency of students is still low, so it can not reach a TOEFL score required by the institution to be able to participate final exam. 
TABLE XI

PRELIMINARY TOEFL SCORE

\begin{tabular}{ccccc}
\hline \hline \multirow{2}{*}{$\begin{array}{c}\text { TOEFL } \\
\text { Score }\end{array}$} & \multicolumn{2}{c}{ Training } & \multicolumn{2}{c}{ Not Training } \\
\cline { 2 - 5 } & $\begin{array}{c}\text { Total } \\
\text { (Persons) }\end{array}$ & $\begin{array}{c}\text { Persentation } \\
(\%)\end{array}$ & $\begin{array}{c}\text { Total } \\
(\text { Persons })\end{array}$ & $\begin{array}{c}\text { Persentation } \\
(\%)\end{array}$ \\
\hline$\leq 476$ & 15 & 100 & 15 & 100 \\
$\geq 477$ & 0 & 0 & 0 & 0 \\
\hline Total & 15 & 100 & 15 & 100 \\
\hline \hline
\end{tabular}

To determine whether the TOEFL Preparation training is effective to increase the TOEFL score, then the grouping of students, ie students who participate in TOEFL preparation training and who did not join the TOEFL preparation training. TOEFL Preparation training is given during the 45 hours of the meeting. TOEFL Preparation training materials consist of 3 (three) topics or focus, ie: (1) Structure and Written Expression, (2) Reading Comprehension, and (3) Listening Comprehension.

After completing training TOEFL preparation, the TOEFL test done again, both on students who attend TOEFL Preparation training or not training TOEFL preparation. Based on the results of the TOEFL test is known that the students taking the TOEFL Preparation training there are 7\% of the students who received TOEFL score $\geq 477$, while $93 \%$ of students still got TOEFL score $<477$. For a group of students who did not attend training TOEFL preparation, known that $100 \%$ of students still got TOEFL score < 477 (Table 12). This indicates that the TOEFL preparation training, followed by students have a positive impact in increasing the TOEFL score of students.

The low value of the percentage of students who got TOEFL score $\geq 477$, which is equal to $7 \%$ indicate that although there has been improvement, but still need to improve the implementation of the training TOEFL preparation, such as the addition timing of the training. Besides the role of institutions is also very important in implementing the policy TOEFL. Institutions in this regard is a study program, are expected to implement policies to make the training TOEFL preparation is part learning curriculum on campus. The presence of the active role of the study program, faculty and students are expected to increase the TOEFL score of students, so that students study period will be shorter.

TABLE XII

FINAL TOEFL SCORE

\begin{tabular}{ccccc}
\hline \hline \multirow{2}{*}{ TOEFL } & \multicolumn{2}{c}{ Training } & \multicolumn{2}{c}{ Not Training } \\
\cline { 2 - 5 } Score & Total & Persentation & Total & $\begin{array}{c}\text { Persentation } \\
\text { (Persons) }\end{array}$ \\
& 14 & $(\%)$ & (Persons) & $(\%)$ \\
\hline$\leq 476$ & 1 & 93 & 15 & 100 \\
$\geq 477$ & 15 & 100 & 0 & 0 \\
\hline Jumlah & & & 15 & 100 \\
\hline \hline
\end{tabular}

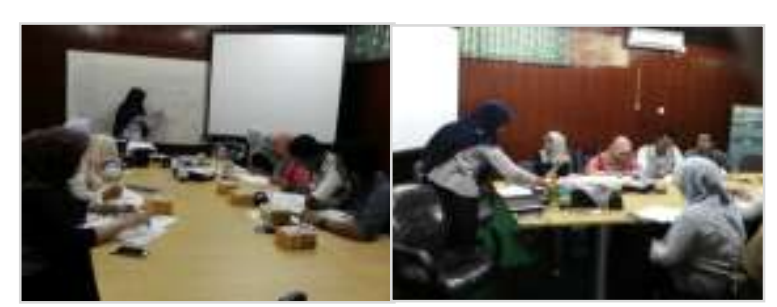

Fig. 3 TOEFL Preparation Training

\section{CONClusion}

Based on the results of this study concluded that: (1) In general, student TOEFL score is $<477$ and to achieve TOEFL score $\geq 477$ students must do the TOEFL test more than five times; (2) The provision of TOEFL preparation training to the students can increase the TOEFL score and reached $\geq 477$; and (3) It needs the active role of the study program, faculty and students to be able to increase the TOEFL score of students, so that students study period will be shorter

\section{ACKNOWLEDGMENT}

This study is funded by Syiah Kuala University, Ministry of Research, Technology and Higher Education in accordance with the Assignment Agreement Implementation Research Number: 1705/UN11/S/PNBP/2016.

\section{REFERENCES}

[1] Burhan, B. (2007). Qualitative research. Jakarta : Kencana.

[2] Goldstein, B.L. (2015). Action Research Projects for Change Management at Syiah Kuala University. Action Research Program Workshop. November 4-5, 2015.

[3] Sabaruddin, Bakhtiar, Zaitun, Syamsuddin, M. Sayuthi, L. Hakim, Sufardi, Efendi, Husni, Hasanuddin, Zainabon. (2016). Guides Curriculum Study Program Magister Agroecoteknologi, Graduate School, Agriculture Faculty, Syiah Kuala University 2016-2020. 98 p.

[4] Sagor, R. 2000. Guiding School Improvement with Action Research. http://www.ascd.org/publications/books/100047/chapters/What-IsAction-research\%C2\%A2.aspx [21 Oktober 2016].

[5] Sugiyono. (2009). Understanding Qualitative Research. Bandung: CV. Alfabeta

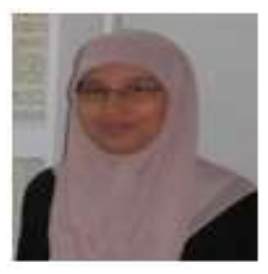

Dr. Zaitun, SP., M.Si. was born in Jakarta, September $13^{\text {th }}, 1972$. She graduated from Undergraduate of Agronomy, Agriculture Faculty, Bogor Agricultural University in 1996; Magister Science of Natural and Environmental Resource Management, Bogor Agricultural University in 1999; and Ph.D of Natural and Environmental Resource Management, Bogor Agricultural University in 2004.

She is working as Lecturer at Agriculture Faculty, Syiah Kuala University, Banda Aceh Indonesia since 2006 until now. She was also involved in several international cooperation between Syiah Kuala Univeristy with several institutions abroad as : (1) Scientific Expert at Asia-Link Project ACULTURE (No. 008/110-005), funded by European Union (2005-2008); (2) Senior Researcher at UNDP with Research Institution, Syiah Kuala University, Nanggroe Aceh Darussalam (2006-2007); (3) Human Resources Management Member at The Netherlans Programme for The Institutional Strengthening of Post-Secondary Education and Training Capacity (2007); (4) Secretary at The Netherlans Programme for The Institutional Strengthening of Post-Secondary Education and Training Capacity (2007-2011); (5) Project Coordinator at The ACIAR (Australian Center for International Agricultural Research) Project. 
International Conference On Literature, English, Religious And Interdisciplinary Studies (LERIS-2017) Jan. 31-Feb. 1, 2017 Bali (Indonesia)

Syiah Kuala University (2009-2013); and (6) Project Coordinator at The ACIAR (Australian Center for International Agricultural Research) Project. Syiah Kuala University (2014-2018). 